IFAS Extension

\title{
Tuttle mealybug Brevennia rehi (Pseudococcidae) ${ }^{1}$
}

\author{
lan Stocks ${ }^{2}$
}

\section{Introduction}

Many grass species are grown as lawns or used in golf courses and other recreational settings in Florida. Turf grasses in Florida are especially susceptible to numerous species of pest insects, and annually millions of dollars are spent to prevent or eliminate infestations. The Tuttle mealybug, Brevennia rehi (Lindinger), is a pest of many grass species and occurs nearly worldwide, especially where rice and sugarcane are grown. Tuttle mealybug has been collected only rarely in Florida, and primarily from southern Florida. Recently, it was collected in Orange County in 2011 and 2012 in association with damage to zoysia grass (Zoysia sp.). This species is also known as the rice mealybug. Rice is an important member of the grass family (Poaceae). Tuttle mealybug was described in the United States as Heterococcus tuttlei Miller and McKenzie (1970) from specimens collected in Arizona and California, but it was subsequently determined to be identical with Brevennia rehi, which occurs throughout the Old World and Oriental region (Williams 1970). The first Florida record (Pompano Beach) of this species was reported by Miller (1975), in which the taxonomic status of Heterococcus tuttlei was amended to junior synonym of Brevennia rehi (Lindinger 1943).

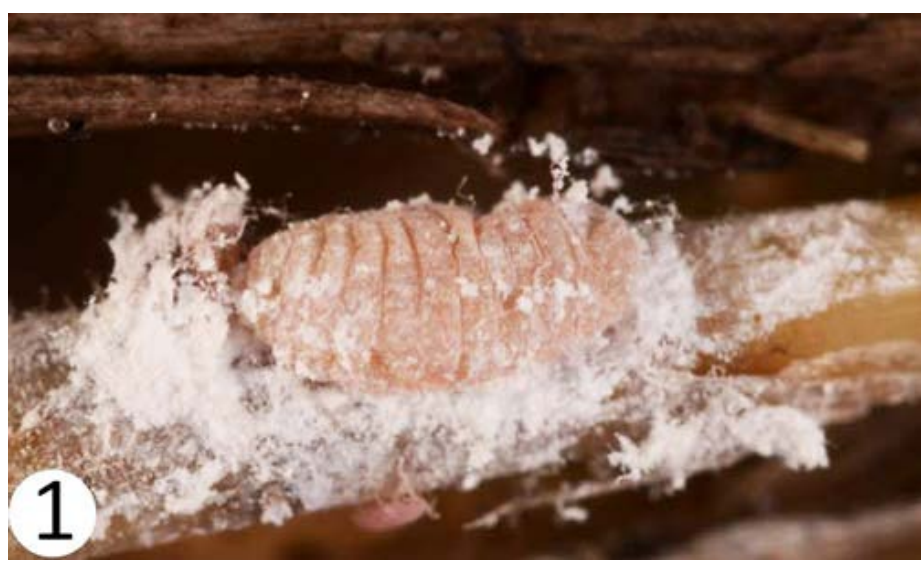

Figure 1. Close-up of Tuttle mealybug, Brevennia rehi, on a stem of zoysia grass. Credits: Lyle Buss, University of Florida, Entomology and Nematology Department.

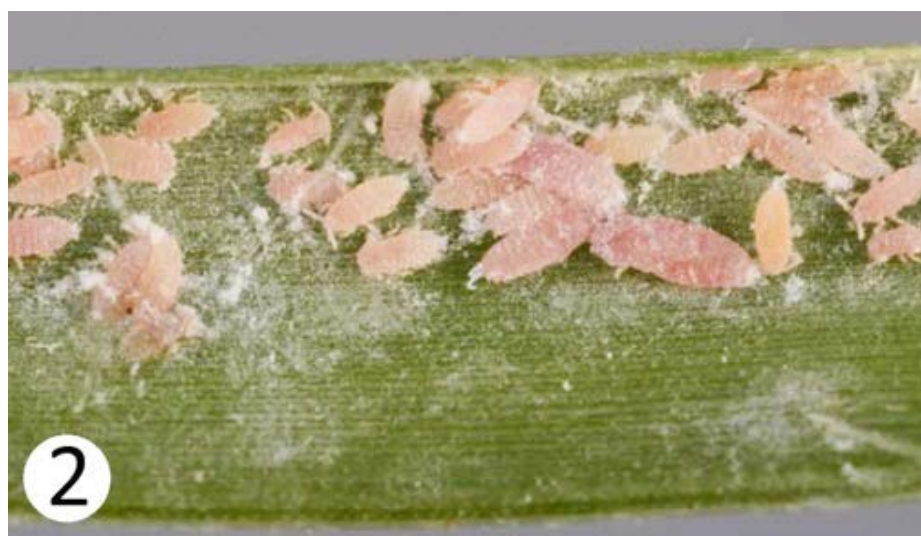

Figure 2. Population of adult and immature Tuttle mealybugs, Brevennia rehi, on a blade of zoysia grass. Credits: Lyle Buss, University of Florida, Entomology and Nematology Department.

1. This document is EENY 551, one of a series of the Entomology and Nematology Department, Florida Cooperative Extension Service, Institute of Food and Agricultural Sciences, University of Florida. Original publication date April 2013. Visit the EDIS website at http://edis.ifas.ufl.edu.

2. Ian Stocks, taxonomic entomologist, Florida Department of Agriculture and Consumer Services, Division of Plant Industry, and affiliate faculty, Entomology and Nematology Department, Institute of Food and Agricultural Sciences, University of Florida, Gainesville, FL 32611. 


\section{Distribution}

Officially recorded in the United States only from Arizona, California, Florida and Texas (Ben-Dov 2012), but is probably more widespread in southeastern states that produce turf grasses for the sod market. Tuttle mealybug is known from other regions of the world (e.g., Palearctic region Afghanistan, Iraq, Iran; Ben- Dov 2012) where there is a distinct cold season, which suggests the mealybug may be capable of surviving in much of the United States.

\section{Description}

The tuttle mealybug is typically small (less than $2 \mathrm{~mm}$ ) and pink, and because they hide between the grass blade and the stem they can be difficult to see (Figures 1-3). Other grass-infesting species, or potentially grass-infesting species, look similar and are difficult to distinguish in the field. Trionymus winnemucae McKenzie (Winnemuca grass mealybug), which is infrequently collected in northern Florida counties, occurs on similar host plants and also lives within the sheath, but may also be found below the crown at the crown-soil interface. Saccharicoccus sacchari (Comstock) (pink sugarcane mealybug) is also an elongated pinkish mealybug that will occasionally infest ornamental grasses, but is more frequently associated in Florida with sugarcane. Both Trionymus winnemucae and Saccharicoccus sacchari are slightly larger, with a more elongate body form.

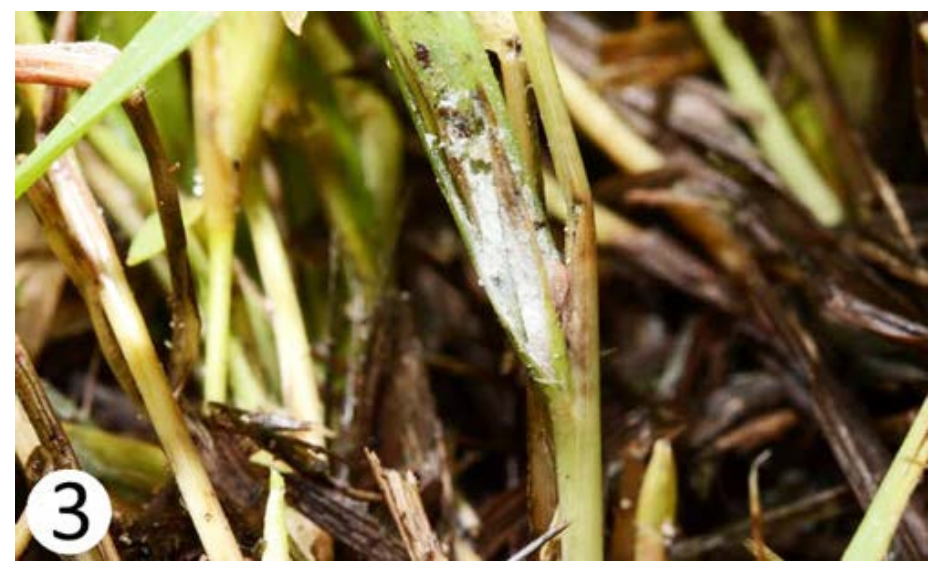

Figure 3. Wax residue of Tuttle mealybugs, Brevennia rehi, on blades of zoysia grass. Credits: Lyle Buss, University of Florida, Entomology and Nematology Department.

\section{Biology}

Several small studies of sporadic, but destructive, infestations in South Asia (e.g., India, Bangladesh) have been published, but generally little is known about the biology of this pest. The authors of one study noted a correlation between drought stress and degree of infestation, possibly due to an increase in the availability of amino acids in the vascular fluid (Dale 1994). This species first came to attention to agriculturists and entomologists in the United States in the late 1960s when it was discovered infesting bermudagrass (Cynodon dactylon (L.) Pers.) seed production crops in Arizona to such an extent that the sticky exudates produced by the mealybugs fouled the harvesting equipment (Miller and McKenzie 1970). Tuttle mealybug is a recorded host of the parasitoids Rhopus nigroclavatus Ashmead and Apoleptomastix bicoloricornis Girault (Hymenoptera: Encyrtidae) (Noyes 2012). Rhopus nigroclavatus does not occur in Florida, but is recorded from several other states, and A. bicoloricornis is not recorded from the United States.

\section{Hosts}

From ScaleNet (Ben-Dov 2012).

Primarily: Poaceae, including Andropogon spp., Cynodon spp., Eleusine spp., Eragrostis spp., Oryza sativa, Panicum spp., Paspalum spp., Saccharum spp., Sorghum vulgare and Zea mays.

Additionally: Cyperus spp. (Cyperaceae) and Juncellus pygmaeus (Juncaceae). From the FDACS-DPI slide collection: Dactyloctenium aegypytium (Miami-Dade Co., North Miami, 15-September 1988); Brachiara and Dactyloctenium (Palm Beach Co., Lake Worth, 3 October 1977); Eleusine indica (Palm Beach Co., Delray Beach, 28 October 1982); Ptychosperma sp. (Miami-Dade Co., Miami, 16 October 2002); Cynodon dactylon (Hillsborough Co., Sun City, 27 July 2007); and Zoysia sp. (Orange Co., 14 August 2012).

\section{Economic Importance}

Because Bermuda and zoysia are important lawn grasses, especially in the southern United States, infestation by Tuttle mealybug should be considered whenever dieback is noticed, especially if the grass blades show white wax or are sticky from honeydew secretion. Both Bermuda and zoysia lawns are commonly installed as sod or plugs, which provide a ready route for the spread of infestations should the pest control practices of the grower fail to maintain a pest-free production environment. Additional collections are needed to establish whether populations of the Tuttle mealybug in the United States have any predators or parasitoids that control them naturally. Because many other mealybugs can also be found on grass, it is necessary to slide-mount specimens for identification. If die-back in lawns is noticed, examine the blades closely for possible mealybug pests (Figure 4) and submit a sample to your county extension agent for further analysis. 


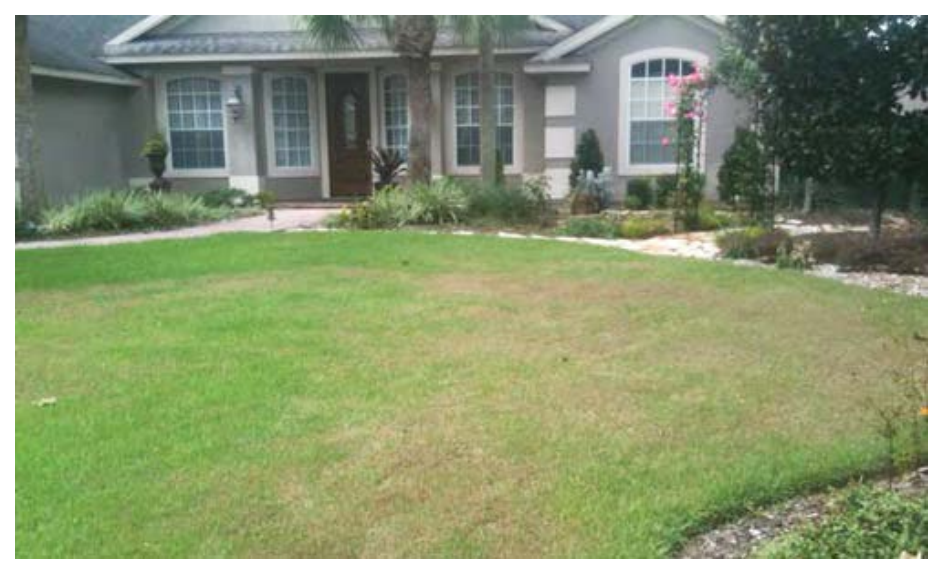

Figure 4. Dieback in zoysia grass due to Tuttle mealybugs, Brevennia rehi. Credits: Roi Levin, Environmental Pest and Lawn Services, Inc.

\section{Selected References}

Ben-Dov Y. 2012. ScaleNet. World Wide Web electronic publication.(5 September 2012.)

Dale D. 1994. Insect pests of the rice plant-their biology and ecology. Pp. 363-486. In: E.A. Heinrichs (ed.) Biology and management of rice insects. Wiley Eastern Limited, New Age International Limited, Bangalore, India.

Miller DR, McKenzie HL. 1970. Review of the genus Heterococcus (Homoptera: Coccoidea: Pseudococcidae) with a description of a new species. Annals of the Entomological Society of America 63: 438-453.

Miller DR. 1975. A revision of the genus Heterococcus Ferris with a diagnosis of the genus Brevennia Goux (Homoptera: Coccoidea: Pseudococcidae). United States Department of Agriculture Technical Bulletin 1497: 1-61.

Noyes JS. 2012. Universal Chalcidoidea Database. World Wide Web electronic publication. (5 September 2012.)

Williams DJ. 1970. The mealybugs (Homoptera, Coccoidea, Pseudococcidae) of sugar-cane, rice and sorghum. Bulletin of Entomological Research 60: 109-188. 